\title{
EFEKTIVITAS MULTIMEDIA INTERAKTIF BERBASIS SAINTIFIK DALAM MENINGKATKAN PRESTASI BELAJAR SISWA DI SD INKLUSIF
}

\author{
Arip Febrianto \\ Pendidikan Guru Sekolah Dasar, Fakultas Keguruan dan Ilmu Pendidikan \\ Universitas PGRI Yogyakarta \\ arip@upy.ac.id \\ Dwi Setianingsih \\ Pendidikan Luar Biasa, Fakultas Keguruan dan Ilmu Pendidikan \\ Universitas PGRI Yogyakarta \\ dwisetianingsih@upy.ac.id
}

\begin{abstract}
Abstrak
Penelitian ini bertujuan untuk menguji efektivitas multimedia interaktif berbasis saintifik dalam meningkatkan prestasi belajar siswa di sekolah dasar inklusi. Penelitian ini menggunakan pendekatan kuantitatif dengan metode quasi teknik pengumpulan data yang digunakan dalam penelitian ini yaitu angket, wawancara, dan observasi. Analisis data yang digunakan adalah uji t dengan taraf signifikansi 0,05. Hasil penelitian menunjukkan bahwa (1) terdapat perbedaan prestasi belajar siswa antara yang menggunakan dan tidak menggunakan multimedia interaktif berbasis saintifik dalam pembelajaran. (2) Multimedia interaktif berbasis saintifik efektif dalam meningkatkan prestasi belajar siswa. Hal ini ditunjukan dari hasil uji coba lapangan yang diperoleh skor uji-t 0,009 dengan Sig. 0,05. Hal itu menunjukkan bahwa terdapat peningkatan prestasi belajar siswa yang signifikan antara sebelum dan setelah pembelajaran menggunakan multimedia interaktif berbasis saintifik. Adanya perbedaan prestasi belajar dengan menggunakan multimedia interaktif berbasis saintifik, dapat dijadikan informasi dan bahan pertimbangan tentang pemanfaatan media yang sesuai dengan karakteristik siswa sehingga diharapkan siswa lebih mudah dalam belajar dan dapat meningkatkan prestasi belajar.
\end{abstract}

Kata Kunci: Multimedia Interaktif, Saintifik, Inklusif

\begin{abstract}
This study aims to test the effectiveness of interactive multimedia based on scientific to increase the achievement of student in inclusion elementary school. This study used a quantitative approach with a quasi-experimental method. Data collection techniques used in this study are questionnaires, interviews, and observations. Data analysis used in this research is $t$ test with a significance level of 0.05 . The results showed that (1) there were differences in student achievement between those who used and did not use interactive multimedia based on scientific learning. (2) Interactive multimedia is effective in improving student learning achievement. This is shown from the results of field trials which obtained the t-test score of 0,009 with Sig. 0,05. This shows that there is a significant increase in student achievement between before and after learning used interactive multimedia based on scientific. The existence of differences in learning achievement using interactive multimedia based on scientific, can be used as information and considerations about the use of media in accordance with student characteristics so that students are expected to be easier to learn and can improve student learning achievement.
\end{abstract}

Keywords: Interactive Multimedia, Scientific, Inclusion 


\section{PENDAHULUAN}

Pemerintah telah memberlakukan sekolah inklusif sebagai wahana bagi pendidikan inklusif melalui Surat Edaran Dirjen Dikdasmen Depdiknas No.380/C.C6/MN/2003 tentang Pendidikan Inklusif (Dirjen Dikdasmen, 2003) bahwa setiap kota/kabupaten menyelenggarakan minimal 4 sekolah inklusif yang terdiri dari SD, SMP, SMA. Konsep utama sekolah inklusif adalah fokus pembelajaran disesuaikan dengan kebutuhan anak dalam belajar. Upaya sekolah inklusif diarahkan untuk: (1) mencegah faktor lingkungan menjadi hambatan belajar anak (upaya preventif); (2) menangani kesulitan belajar pada anak (upaya intervensi); dan (3) menggantikan fungsi yang hilang atau mengalami hambatan dengan fungsi yang lain (upaya kompensasi) (Alimin, 2013).

Dalam hal keberagaman kemampuan dan kebutuhan siswa khususnya pada tingkat Sekolah Dasar, upaya intervensi mutlak diperlukan. Intervensi guru dalam proses pembelajaran disesuaikan dengan kesulitan dan hambatan yang siswa alami. Adanya tekanan kurikulum, keterbatasan waktu dan pemahaman guru tentang keberagaman kemampuan siswa, semakin membuat siswa dengan hambatan perkembangan 'tertinggal' dalam pembelajaran. Untuk mengatasi permasalahan tersebut, dibutuhkan suatu pengembangan model pendidikan inklusi yang memudahkan kinerja guru dalam menghadapi keberagaman kemampuan siswa dan mengatasi hambatan yang dialami siswa.

Salah satu upaya intervensi tersebut adalah pembelajaran menggunakan pendekatan saintifik melalui multimedia interaktif untuk membantu siswa berkebutuhan khusus. Pembelajaran berbasis saintifik merupakan pembelajaran dengan memperhatikan penilaian terhadap proses dan hasil belajar siswa, sedangkan multimedia interaktif merupakan media pembelajaran berbasis teknologi yang menekankan respon pengguna (siswa) sehingga siswa dapat belajar sesuai dengan kebutuhan dan tipe belajarnya. Penerapan multimedia interaktif berbasis saintifik ini dapat memudahkan guru dalam menangani hambatan yang dialami oleh siswa, sehingga proses pembelajaran dapat efektif dan efisien. Melalui multimedia interaktif berbasis saintifik ini diharapkan kemampuan dan kebutuhan siswa berkebutuhan khusus yang bersekolah di sekolah dasar inklusif akan semakin terakomodasi dengan baik sehingga dapat berdampak positif terhadap prestasi belajar mereka. Tujuan penelitian ini adalah membuktikan efektivitas multimedia interaktif berbasis saintifik untuk meningkatkan prestasi belajar siswa di sekolah dasar inklusi. Selain itu, penelitian ini memiliki manfaat bagi pendidik, bagi instansi pendidikan, serta bagi peneliti selanjutnya. 


\section{METODE}

Penelitian ini dilakukan dengan model penelitian quasi eksperimen. Adapun desain penelitiannya yaitu menggunakan pre-test and post-test group. Di dalam desain ini, observasi dilakukan sebanyak 2 kali yaitu sebelum treatment dan sesudah treatment. Dalam penelitian ini, observasi yang dilakukan yaitu untuk mengetahui prestasi belajar siswa. Selisih antara O1 dan O2 yakni O2 - O1 diasumsikan merupakan efek dari treatment atau perlakuan. Instrumen pengumpulan data yang digunakan yaitu: pedoman wawancara, lembar observasi, dan angket. Teknik analisis data yang dilakukan yaitu: uji prasyarat (uji normalitas dan homogenitas) dan uji beda dua rata-rata (Paired Sample T-Test). Pengujian ini dilakukan terhadap dua sampel yang berpasangan (paired). Sampel yang berpasangan adalah sampel dengan subjek yang sama namun mengalami dua perlakuan atau pengukuran yang berbeda. Uji statistik dengan (Paired Sample TTest) digunakan untuk menjelaskan ada atau tidaknya perbedaan signifikan pada prestasi belajar siswa dengan atau tanpa menggunakan multimedia interaktif berbasis saintifik. Subjek penelitian ini adalah siswa kelas II SD Muhammadiyah Ambarketawang 2 Kota Yogyakarta.

\section{HASIL DAN PEMBAHASAN}

Penelitian ini menggunakan penelitian quasi eksperimen dengan membandingkan hasil postes yang menggunakan multimedia interaktif berbasis saintifik dan hasil pretes yang belum menggunakan multimedia interaktif berbasis saintifik. Subyek yang dijadikan penelitian adalah siswa kelas II SD Muhammadiyah 2 Yogyakarta yang terdiri dari 17 siswa. Prestasi belajar siswa meningkat setelah pembelajaran menggunakan multimedia interaktif berbasis saintifik. Hal ini dapat dilihat dari nilai rata-rata posttest siswa yang mengalami peningkatan dibandingkan rata-rata pretest siswa. Nilai rata-rata pretest prestasi belajar siswa yaitu 69,06 dengan nilai terendah yaitu 48 dengan frekuensi 1 siswa. Nilai tertinggi yang diperoleh yaitu 81 dengan frekuensi 1 siswa, sedangkan nilai rata-rata posttest prestasi belajar adalah 84,64 dengan nilai terendah yaitu 75 dengan frekuensi 1 siswa. Nilai tertinggi yang diperoleh dari yaitu 94 dengan frekuensi 2 siswa. Rata-rata nilai pretes dan postes prestasi belajar siswa sebelum dan sesudah pembelajaran menggunakan multimedia interaktif berbasis saintifik dapat dilihat pada gambar berikut. 


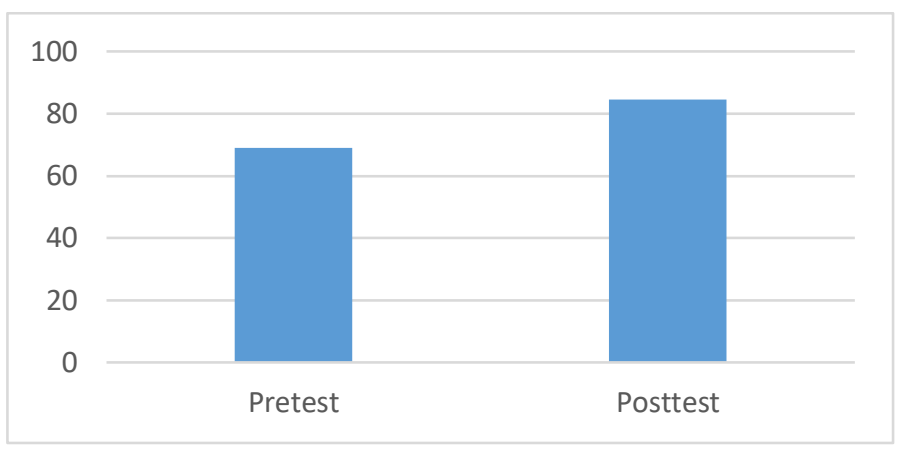

Gambar 1. Rata-rata nilai pretes dan postes

Dilihat dari besarnya rata-rata nilai pretes dan nilai postes diketahui bahwa rata-rata postes lebih tinggi dari nilai pretes, sehingga terdapat perbedaan prestasi belajar siswa antara siswa yang menggunakan dan tidak menggunakan multimedia interaktif dalam pembelajaran. Sebelum peneliti memberi perlakuan, terlebih dahulu dilakukan uji prasyarat analisis yang berupa uji normalitas dan uji homogenitas pada kedua kelas untuk mengetahui data kedua kelas normal dan homogen. Berdasarkan uji normalitas menggunakan Kolmogorov-Smirnov Z, pretes prestasi belajar siswa diperoleh 0,730 dengan Asymp. Sig (2- tailed) >0,05, maka H0 diterima; dan Kolmogorov-Smirnov Z postes prestasi belajar siswa diperoleh 0,692 dengan Asymp. Sig (2tailed) >0,05 maka Ho diterima. Hasil uji homogenitas menunjukkan bahwa Levene Statistic dan Sig. prestasi belajar diperoleh 0,742 dan 0,103, maka Ho diterima. Dengan demikian dapat disimpulkan bahwa varians dari kedua kelompok berdistribusi normal dan homogen maka prasyarat uji hipotesis telah terpenuhi. Dengan demikian analisis untuk menguji hipotesis awal dapat dilakukan. Hasil uji hipotesis menunjukan bahwa nilai t hitung 0,009 dengan Sig. (2-tailed) $>0,05$ maka H0 ditolak. Dari pertimbangan yaitu melihat t hitung menunjukan bahwa ada perbedaan prestasi belajar siswa antara siswa yang belajar menggunakan dan tidak menggunakan multimedia interaktif. Jadi hipotesis yang diajukan peneliti diterima.

Multimedia interaktif berbasis saintifik efektif dalam meningkatkan prestasi belajar siswa. Meningkatnya prestasi belajar ini juga didukung oleh hasil penelitian Zakiyah (2015) yang menyatakan bahwa ada pengaruh penerapan pendekatan pembelajaran saintifik terhadap hasil belajar Ilmu Pengetahuan Alam (IPA) pada anak tunanetra kelas I di SDLB A YPAB Tegalsari Surabaya. Sementara itu (Susanti, 2016) menjelaskan bahwa penerapan pendekatan saintifik bagi anak berkebutuhan khusus masih menghadapi kendala tersendiri dalam pengimplementasiannya. Guru mengalami kesulitan apabila menerapkan pembelajaran langsung di luar kelas, guru harus menyesuaikan dengan kondisi anak serta perlunya penyesuaian materi pembelajaran sesuai dengan kemampuan anak. 
Berdasarkan hasil penelitian tersebut, multimedia interaktif berbasis saintifik dapat meningkatkan pemahaman siswa, dengan meningkatnya pemahaman siswa, siswa akan mudah dalam memahami materi dan pada akhirnya prestasi belajar siswa akan meningkat, sehingga berdasarkan kajian di atas, multimedia interaktif berbasis saintifik dapat meningkatkan prestasi belajar siswa. Hasil penelitian sejalan lainnya yaitu penelitian dari Sukadari \& Komalasari (2017: 127) yang menyatakan bahwa terdapat perbedaan prestasi belajar antara sebelum dan setelah menggunakan multimedia interaktif. Hasil penelitian Komalasari, M. D., \& Pamungkas, B. (2019) menunjukkan bahwa multimedia interaktif berbasis multisensoris terbukti meningkatkan prestasi belajar siswa yang ditunjukkan oleh peningkatan jumlah siswa yang mencapai Kriteria Keuntasan Minimal (KKM) dan peningkatan nilai rata-rata tes.

Hasil penelitian ini dapat digunakan sebagai bahan pertimbangan bagi guru, untuk menggunakan media pembelajaran inovatif, seperti multimedia interaktif berbasis saintifik, untuk lebih memperhatikan sarana prasarana dan kebutuhan siswanya agar dapat meningkatkan prestasi belajar siswa. Pembelajaran menggunakan multimedia interaktif berbasis saintifik menjadi pembelajaran yang menarik bagi siswa karena dengan media pembelajaran ini siswa dapat mengamati, menanya, mengumpulkan informasi, mengasosiasikan, dan mengkomunikasikan materi ajar. Dengan penerapan multimedia interaktif pada sekolah inklusif akan membantu mengakomodir kebutuhan siswa pada berbagai mata pelajaran yang ditemakan.

\section{PENUTUP}

\section{Simpulan}

Kesimpulan hasil penelitian ini adalah sebagai berikut. (1) Multimedia interaktif berbasis saintifik layak digunakan untuk meningkatkan prestasi belajar siswa di sekolah dasar inklusi; (2) Berdasarkan hasil penelitian di atas diketahui bahwa nilai signifikansi prestasi belajar siswa antara sebelum dan sesudah pembelajaran menggunakan multimedia interaktif berbasis saintifik adalah 0,000, maka terdapat peningkatan prestasi belajar siswa setelah pembelajaran menggunakan multimedia interaktif berbasis saintifik, sehingga multimedia interaktif berbasis saintifik efektif digunakan dalam meningkatkan prestasi belajar siswa di sekolah dasar inklusif.

\section{Saran}

Saran berdasarkan simpulan penelitian ini adalah perlu dikembangkanya multimedia interaktif berbasis saintifik pada berbagai materi ajar dan disesuaikan dengan berbagai hambatan belajar siswa khususnya siswa dengan kebutuhan khusus di sekolah inklusif. 


\section{DAFTAR PUSTAKA}

Alimin, Z. 2013. Pendidikan Anak Berkebutuhan Khusus. Bandung: PKh UPI.

Arum, W., S., A. 2005. Perspektif Pendidikan Luar Biasa dan Implikasinya Bagi Penyiapan Tenaga Kependidikan. Jakarta: Direktorat Dikti.

Arsyad, Azhar. 2011. Media Pembelajaran. Jakarta: PT Raja Grafindo Persada.

BPSDMPK. 2013. Panduan Kurikulum 2013. Jakarta: Kemendikbud.

Daryanto. 2010. Media Pembelajaran. Yogyakarta: Gava Media.

Dirjen Dikdasmen. (2003). Surat Edaran Dirjen Dikdasmen No.380/C.C6/MN/2003, tentang Pendidikan Inklusif.

Komalasari, M. D., \& Pamungkas, B. 2019. Meningkatkan Pemahaman Konsep Perkalian dan Pembagian Menggunakan Multimedia Interaktif Berbasis Multisensoris Pada Siswa Berkesulitan Belajar. Elementary School (Jurnal Pendidikan dan Pembelajaran Ke-SD-an, 6 (1).

Sukadari \& Komalasari, M.D. 2017. Pengembangan Multimedia Interaktif Berbasis Nilai Karakter UPY "Karakterku” untuk Meningkatkan Karakter Mahasiswa UPY. G-COUNS. Jurnal Bimbingan dan Konseling, 2 (1).

Susanti, L. 2016. Implementasi Kurikulum 2013 Pada Anak Tunagrahita di SLB AC. Jurnal Pendidikan Khusus, 8(2).

Zakiyah, Z. 2015. Pendekatan Pembelajaran Saintifik Terhadap Hasil Belajar Ilmu Pengetahuan Alam (IPA) Pada Anak Tunanetra Kelas I. Jurnal Pendidikan Khusus, 7(3). 